\title{
Synthesis, crystal structures, and photoluminescence of two silver(I) coordination polymers based on 2 -sulfoterephthalic acid and N-donor ligands
}

\author{
Jie Wang $\cdot$ Jia-Guo Wang $\cdot$ Xin-Hua Li $\cdot$ \\ Hong-Ping Xiao
}

Received: 11 May 2013/Accepted: 28 June 2013/Published online: 12 July 2013

(C) The Author(s) 2013. This article is published with open access at Springerlink.com

\begin{abstract}
The reactions of 2-sulfoterephthalic acid $\left(\mathrm{H}_{3} \mathrm{stp}\right)$ with silver nitrate in the presence of 2-aminopyrimidine (apym) or 2-amino-4,6-dimethylpyrimidine (dapym) generated two 2-D coordination polymers $\left\{\left[\mathrm{Ag}_{3}(\mathrm{stp})(\text { apym })_{3}\right] \cdot 2 \mathrm{H}_{2} \mathrm{O}\right\}_{n}(\mathbf{1})$ and $\left\{\left[\mathrm{Ag}_{2}(\mathrm{Hstp})(\text { dapym })_{2}\right.\right.$ $\left.\left.\left(\mathrm{H}_{2} \mathrm{O}\right)\right] \cdot \mathrm{H}_{2} \mathrm{O}\right\}_{n}(2)$. The complexes have been characterized by single-crystal $\mathrm{X}$-ray diffraction, physico-chemical, and spectroscopic methods. Both complexes have a 2-D layer structure with infinite $1-\mathrm{D}$ chains linked by $\operatorname{stp}^{3-}$ ligands and hydrogen bonds. The luminescent properties of the complexes were investigated.
\end{abstract}

\section{Introduction}

Reasons for the current interest in the crystal engineering of silver coordination polymers include their interesting mechanisms of molecular self-assembly [1-3], abundant weak interactions [4-6], potential applications in many areas such as electrical conductivity [7], magnetism [8], and catalysis [9] and so forth. Silver(I) atoms can accommodate a wide variety of stereochemistries, with coordination numbers of two to six and versatile coordination geometries, including linear, T-shaped, square-planar, tetrahedral, square-pyramidal, trigonal-bipyramidal, and octahedral [10-13]. Furthermore, Ag(I) with a d ${ }^{10}$ closedshell electronic configuration tends to form argentophilic interactions, which have an important influence on the formation of polymetallic clusters [14-16]. In particular,

J. Wang $\cdot$ J.-G. Wang $\cdot$ X.-H. Li $\cdot$ H.-P. Xiao $(\bowtie)$

College of Chemistry and Materials Engineering, Wenzhou

University, Wenzhou 325035, People's Republic of China

e-mail: jwwzedu@163.com
Ag(I) complexes with carboxylate ligands have been widely investigated for their intriguing structural topologies and potential applications [17-20]. We selected 2 -sulfoterephthalic acid as an organic ligand, based on the following twofold considerations. First, the two carboxylate groups and one sulfonate group of the ligand could act as bridging groups to form coordination polymers [21-24]; second, the protons of the ligand, if not all dissociated, could form $\mathrm{H}$-bonds with adjacent ligands or solvent molecules [10, 25]. In addition, the introduction of $\mathrm{N}$-donor organic ligands is an important strategy for the construction of novel coordination polymers [26-28].

Taking into account these considerations, and following on from our previous work [29], we have studied the selfassembly of $\mathrm{Ag}(\mathrm{I})$ with $\mathrm{H}_{3}$ stp and auxiliary $\mathrm{N}$-donor ligands. In this paper, we report the syntheses, crystal structures, and properties of two new silver(I) coordination

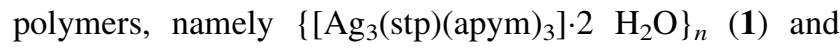
$\left\{\left[\mathrm{Ag}_{2}(\mathrm{Hstp})(\text { dapym })_{2}\left(\mathrm{H}_{2} \mathrm{O}\right)\right] \cdot \mathrm{H}_{2} \mathrm{O}\right\}_{n}(\mathbf{2})$.

\section{Experimental}

Materials and instrumentation

All chemicals and solvents were obtained from commercial sources as reagent grade and used without further purification in the syntheses. Elemental analyses for $\mathrm{C}, \mathrm{H}$, and $\mathrm{N}$ were obtained with a CHN-O-Rapid Analyzer and an Elemental Vario Microanalyzer. The infrared spectra were taken on a Bruker Equinox 55 FTIR spectrometer as $\mathrm{KBr}$ pellets in the $400-4,000 / \mathrm{cm}^{-1}$ region. The fluorescence spectra were measured using a Shimadzu RF-7000 spectrometer on powdered samples in the solid state at room temperature. 
Synthesis of $\left\{\left[\mathrm{Ag}_{3}(\mathrm{stp})(\text { apym })_{3}\right] \cdot 2 \mathrm{H}_{2} \mathrm{O}\right\}_{n}(\mathbf{1})$

A solution of $\mathrm{AgNO}_{3}(0.0338 \mathrm{~g}, 0.20 \mathrm{mmol})$ in water $(10 \mathrm{ml})$ was added to a stirred solution of 2-sulfoterephthalic acid $(0.0536 \mathrm{~g}, 0.20 \mathrm{mmol})$ and 2-aminopyrimidine $(0.019 \mathrm{~g}, 0.20 \mathrm{mmol})$ in $\operatorname{DMF}(5 \mathrm{ml})$. The mixture was stirred for $10 \mathrm{~min}$ and then the precipitate was filtered off; the filtrate was allowed to evaporate in the dark. After 2 weeks, colorless block-shaped crystals were obtained. Yield $0.07 \mathrm{~g}(40 \%)$. Anal. Calcd for $\mathrm{C}_{20} \mathrm{H}_{22} \mathrm{Ag}_{3} \mathrm{~N}_{9} \mathrm{O}_{9} \mathrm{~S}$ : C 27.1, H 2.5, N 14.2 \%; Found: C 27.0, H 2.4, N $14.1 \%$; FTIR ( $\mathrm{KBr}$ pellet, $\mathrm{cm}^{-1}$ ) selected bands: $v=3,856 \mathrm{w}$, $3,740 \mathrm{w}, 3,403 \mathrm{~s}, 3,314 \mathrm{~s}, 3,178 \mathrm{~m}, 1,577 \mathrm{~s}, 1,479 \mathrm{~s}$, $1,360 \mathrm{~s}, 1,203 \mathrm{~s}, 1,072 \mathrm{~m}, 1,022 \mathrm{~m}, 799 \mathrm{~m}, 676 \mathrm{w}, 621 \mathrm{~m}$, $574 \mathrm{w}, 508 \mathrm{~m}$.

\section{Synthesis of $\left\{\left[\mathrm{Ag}_{2}(\mathrm{Hstp})(\text { dapym })_{2}\left(\mathrm{H}_{2} \mathrm{O}\right)\right] \cdot \mathrm{H}_{2} \mathrm{O}\right\}_{n}(2)$}

A solution of $\mathrm{AgNO}_{3}(0.0338 \mathrm{~g}, 0.20 \mathrm{mmol})$ in water $(10 \mathrm{ml})$ was added to a stirred solution of 2-sulfoterephthalic acid $(0.0536 \mathrm{~g}, 0.20 \mathrm{mmol})$ and 2-amino-4,6-dimethylpyrimidine $(0.0246 \mathrm{~g}, 0.20 \mathrm{mmol})$ in a mixture of $\mathrm{DMF}(5 \mathrm{ml})$ and $\mathrm{CH}_{3} \mathrm{CN}(5 \mathrm{ml})$. The mixture was stirred for $10 \mathrm{~min}$ and then the precipitate was filtered off; the filtrate was allowed to evaporate in the dark. After 2 weeks, colorless sheet crystals were obtained. Yield $0.06 \mathrm{~g}(38 \%)$. Anal. Calcd for $\mathrm{C}_{20} \mathrm{H}_{26} \mathrm{Ag}_{2} \mathrm{~N}_{6} \mathrm{O}_{9} \mathrm{~S}$ : C 32.4, H 3.5, N $11.3 \%$; Found: C 32.3, H 3.5, N $11.3 \%$; FTIR ( $\mathrm{KBr}$ pellet, $\mathrm{cm}^{-1}$ ) selected bands: $v=3,856,3,741 \mathrm{w}, 3,508 \mathrm{~m}$,

Table 1 Crystal data for complexes 1 and 2

\begin{tabular}{|c|c|c|}
\hline Complex & 1 & 2 \\
\hline Empirical formula & $\mathrm{C}_{20} \mathrm{H}_{22} \mathrm{Ag}_{3} \mathrm{~N}_{9} \mathrm{O}_{9} \mathrm{~S}$ & $\mathrm{C}_{20} \mathrm{H}_{26} \mathrm{Ag}_{2} \mathrm{~N}_{6} \mathrm{O}_{9} \mathrm{~S}$ \\
\hline$M_{\mathrm{r}}$ & 888.14 & 742.27 \\
\hline Crystal system & Triclinic & Monoclinic \\
\hline Space group & $P_{-1}$ & $P 2{ }_{1} / \mathrm{c}$ \\
\hline$a(\AA)$ & $8.4598(5)$ & $9.8955(14)$ \\
\hline$b(\AA)$ & $8.7939(5)$ & $22.883(3)$ \\
\hline$c(\AA)$ & $18.5836(11)$ & $13.5489(13)$ \\
\hline$\alpha\left({ }^{\circ}\right)$ & $80.2270(10)$ & 90 \\
\hline$\beta\left(^{\circ}\right)$ & $81.5540(10)$ & $124.005(7)$ \\
\hline$\gamma\left({ }^{\circ}\right)$ & $74.6730(10)$ & 90 \\
\hline $\mathrm{V}\left(\AA^{3}\right)$ & $1,306.41(13)$ & $2,543.3(5)$ \\
\hline$Z$ & 2 & 4 \\
\hline$\theta$ range $\left({ }^{\circ}\right)$ & $1.12-25.10$ & $2.02-25.50$ \\
\hline$D_{\text {calc }}\left(\mathrm{Mg} \mathrm{m}^{-3}\right)$ & 2.258 & 1.939 \\
\hline$\mu\left(\mathrm{mm}^{-1}\right)$ & 2.377 & 1.684 \\
\hline$F(000)$ & 868 & 1,480 \\
\hline$R_{1}[\mathrm{I}>2 \sigma]$ & 0.0287 & 0.0308 \\
\hline$w R_{2}$ (all data) & 0.0361 & 0.0325 \\
\hline
\end{tabular}

$R_{I}^{a}=\Sigma\left\|F_{\mathrm{o}}|-| F_{\mathrm{c}}\right\| / \Sigma F_{\mathrm{o}} \mid \cdot w R_{2}^{b}=\left[\Sigma w\left(F_{\mathrm{o}}^{2}-F_{\mathrm{c}}^{2}\right)^{2} / \Sigma w\left(F_{\mathrm{o}}^{2}\right)\right]^{1 / 2}$
$3,393 \mathrm{~s}, 3,213 \mathrm{~m}, 1,937 \mathrm{~m}, 1,647 \mathrm{~s}, 1,589 \mathrm{~s}, 1,475 \mathrm{~m}$, $1,427 \mathrm{~m}, 1,372 \mathrm{~s}, 1,285 \mathrm{~m}, 1,223 \mathrm{~s}, 1,074 \mathrm{~m}, 1,023 \mathrm{~m}$, 789 m, 728 w, 672 w, 624 m, 572 w, 496 m.

X-ray crystallographic study

The X-ray single-crystal data for complexes $\mathbf{1}$ and $\mathbf{2}$ were recorded on a Brucker APEX II area detector diffractometer with graphite-monochromated $\mathrm{MoK} \alpha$ radiation ( $k=0.71073 \AA$ ). Semi-empirical absorption corrections were applied using the SADABS program. The structures were solved by direct methods and refined by full-matrix least squares on $F^{2}$ using SHELXL-97. All non-hydrogen atoms were refined anisotropically. The carboxyl and water $\mathrm{H}$ atoms were located from difference Fourier maps; other hydrogen atoms were placed in geometrically calculated positions. Experimental details for X-ray data collection of $\mathbf{1}$ and $\mathbf{2}$ are presented in Table 1, and selected bond lengths are listed in Table 2.

\section{Results and discussion}

\section{Structure of complex 1}

Single-crystal X-ray diffraction analysis reveals that $\left\{\left[\mathrm{Ag}_{3}(\mathrm{stp})(\operatorname{apym})_{3}\right] \cdot 2 \mathrm{H}_{2} \mathrm{O}\right\}_{n}(\mathbf{1})$ presents a 2-D sheet based on a 1-D double chain, which crystallizes in the space group $P_{-1}$. There are three $\operatorname{Ag}(\mathrm{I})$ atoms, one 2-stp ligand, three apym ligands, and two lattice water molecules in the asymmetric unit of $\mathbf{1}$. As depicted in Fig. 1a, three crystallographically different $\operatorname{Ag}(\mathrm{I})$ atoms are located in an approximate $\mathrm{T}$-shaped coordination geometry and coordinated by one oxygen from the same 2-stp ligand and two nitrogen atoms from two different apym ligands. The Ag-O bond distances vary from 2.283 (3) to 2.509(3) $\AA$, and the $\mathrm{Ag}-\mathrm{N}$ bond lengths range between 2.190(3) and 2.330(4) $\AA$. Both $\mathrm{Ag}-\mathrm{O}$ and $\mathrm{Ag}-\mathrm{N}$ bond lengths are well matched with those observed in similar complexes [10-14, 29].

The $\operatorname{Ag}(\mathrm{I})$ atoms are linked by bidentate apym ligands to form 1-D zigzag chains in which the apym ligands are oppositely arranged, and the stp ligands extend the 1-D single chains into a 1-D double chain, containing classical hydrogen bonds (Fig. 1c). Subsequently, with $\mathrm{Ag} 2$ as a node, two pairs of reverse direction 1-D double chains link adjacent sulfo group oxygen atoms (O3) from stp ligands into a 2-D laminar framework (Fig. 1b). In addition, the amino groups of apym ligands form hydrogen bonds with the coordinated $\mathrm{O} 5$ of the carboxyl groups and water molecules, while the water molecule form hydrogen bonds with the coordinated $\mathrm{O} 2$ and $\mathrm{O} 5$ atoms of the carboxyl groups (as depicted in Table 3). 
Table 2 Selected bond lengths $(\AA)$ angles $\left({ }^{\circ}\right)$ for complexes $\mathbf{1}$ and $\mathbf{2}$

\begin{tabular}{|c|c|c|c|c|c|}
\hline $\multicolumn{6}{|c|}{\left[\mathrm{Ag}_{3}(\operatorname{stp})(\operatorname{apym})_{3}\right] \cdot 2 \mathrm{H}_{2} \mathrm{O}}_{n}(\mathbf{1})$ \\
\hline \multicolumn{6}{|l|}{ Bond lengths $(\AA)$} \\
\hline $\mathrm{Ag}(1)-\mathrm{O}(1)$ & $2.499(3)$ & $\operatorname{Ag}(1)-N(1)$ & $2.206(3)$ & $\operatorname{Ag}(1)-\mathrm{N}(9) \# 1$ & $2.190(3)$ \\
\hline $\operatorname{Ag}(2)-O(3)$ & $2.509(3)$ & $\operatorname{Ag}(2)-N(7)$ & $2.233(3)$ & $\operatorname{Ag}(3)-O(6)$ & $2.283(3)$ \\
\hline $\operatorname{Ag}(3)-\mathrm{N}(3) \# 2$ & $2.226(3)$ & $\operatorname{Ag}(3)-N(6) \# 3$ & $2.330(4)$ & & \\
\hline \multicolumn{6}{|l|}{ Bond angles $\left({ }^{\circ}\right)$} \\
\hline $\mathrm{N}(9) \# 1-\operatorname{Ag}(1)-\mathrm{N}(1)$ & $157.91(12)$ & $\mathrm{N}(9) \# 1-\mathrm{Ag}(1)-\mathrm{O}(1)$ & $98.97(12)$ & $\mathrm{N}(1)-\operatorname{Ag}(1)-\mathrm{O}(1)$ & $102.85(12)$ \\
\hline $\mathrm{N}(7)-\operatorname{Ag}(2)-\mathrm{N}(4)$ & 153.11(13) & $\mathrm{N}(7)-\operatorname{Ag}(2)-\mathrm{O}(3)$ & $97.28(11)$ & $\mathrm{N}(4)-\operatorname{Ag}(2)-\mathrm{O}(3)$ & $108.11(11)$ \\
\hline $\mathrm{O}(6)-\mathrm{Ag}(3)-\mathrm{N}(6) \# 3$ & $98.35(12)$ & $\mathrm{N}(3) \# 2-\mathrm{Ag}(3)-\mathrm{N}(6) \# 3$ & $124.68(12)$ & $\mathrm{N}(3) \# 2-\mathrm{Ag}(3)-\mathrm{O}(6)$ & $132.10(12)$ \\
\hline \multicolumn{6}{|c|}{ Symmetry codes: \#1 $(-x+2,-y+1,-z) ; \# 2(-x+2,-y,-z+1) ; \# 3(x, y-1, z)$} \\
\hline $\multicolumn{6}{|c|}{\left[\mathrm{Ag}_{2}(\mathrm{Hstp})(\text { dapym })_{2}\left(\mathrm{H}_{2} \mathrm{O}\right)\right] \cdot \mathrm{H}_{2} \mathrm{O}}_{n}(\mathbf{2})$ \\
\hline \multicolumn{6}{|l|}{ Bond lengths $(\AA)$} \\
\hline $\operatorname{Ag}(1)-N(4)$ & $2.200(3)$ & $\operatorname{Ag}(1)-\mathrm{N}(1)$ & $2.202(3)$ & $\operatorname{Ag}(1)-O(1)$ & $2.494(2)$ \\
\hline $\operatorname{Ag}(2)-O(8)$ & $2.444(3)$ & $\operatorname{Ag}(2)-O(4)$ & $2.715(6)$ & $\operatorname{Ag}(2)-N(2) \# 1$ & $2.250(3)$ \\
\hline $\operatorname{Ag}(2)-\mathrm{N}(5) \# 2$ & $2.285(3)$ & & & & \\
\hline \multicolumn{6}{|l|}{ Bond angles $\left({ }^{\circ}\right)$} \\
\hline $\mathrm{N}(4)-\operatorname{Ag}(1)-\mathrm{N}(1)$ & $157.36(9)$ & $\mathrm{N}(1)-\mathrm{Ag}(1)-\mathrm{O}(1)$ & $99.04(9)$ & $\mathrm{N}(4)-\operatorname{Ag}(1)-\mathrm{O}(1)$ & $96.96(9)$ \\
\hline $\mathrm{O}(8)-\mathrm{Ag}(2)-\mathrm{O}(4)$ & 99.34(19) & $\mathrm{N}(2) \# 1-\mathrm{Ag}(2)-\mathrm{O}(8)$ & $100.50(10)$ & $\mathrm{N}(5) \# 2-\mathrm{Ag}(2)-\mathrm{O}(8)$ & $94.24(10)$ \\
\hline $\mathrm{N}(2) \# 1-\mathrm{Ag}(2)-\mathrm{O}(4)$ & $112.97(14)$ & $\mathrm{N}(5) \# 2-\mathrm{Ag}(2)-\mathrm{O}(4)$ & $93.80(14)$ & $\mathrm{N}(2) \# 1-\mathrm{Ag}(2)-\mathrm{N}(5) \# 2$ & $150.79(9)$ \\
\hline \multicolumn{6}{|c|}{ Symmetry codes: $\# 1(x,-y+3 / 2, z+1 / 2) ; \# 2(-x,-y+1,-z+1)$} \\
\hline
\end{tabular}
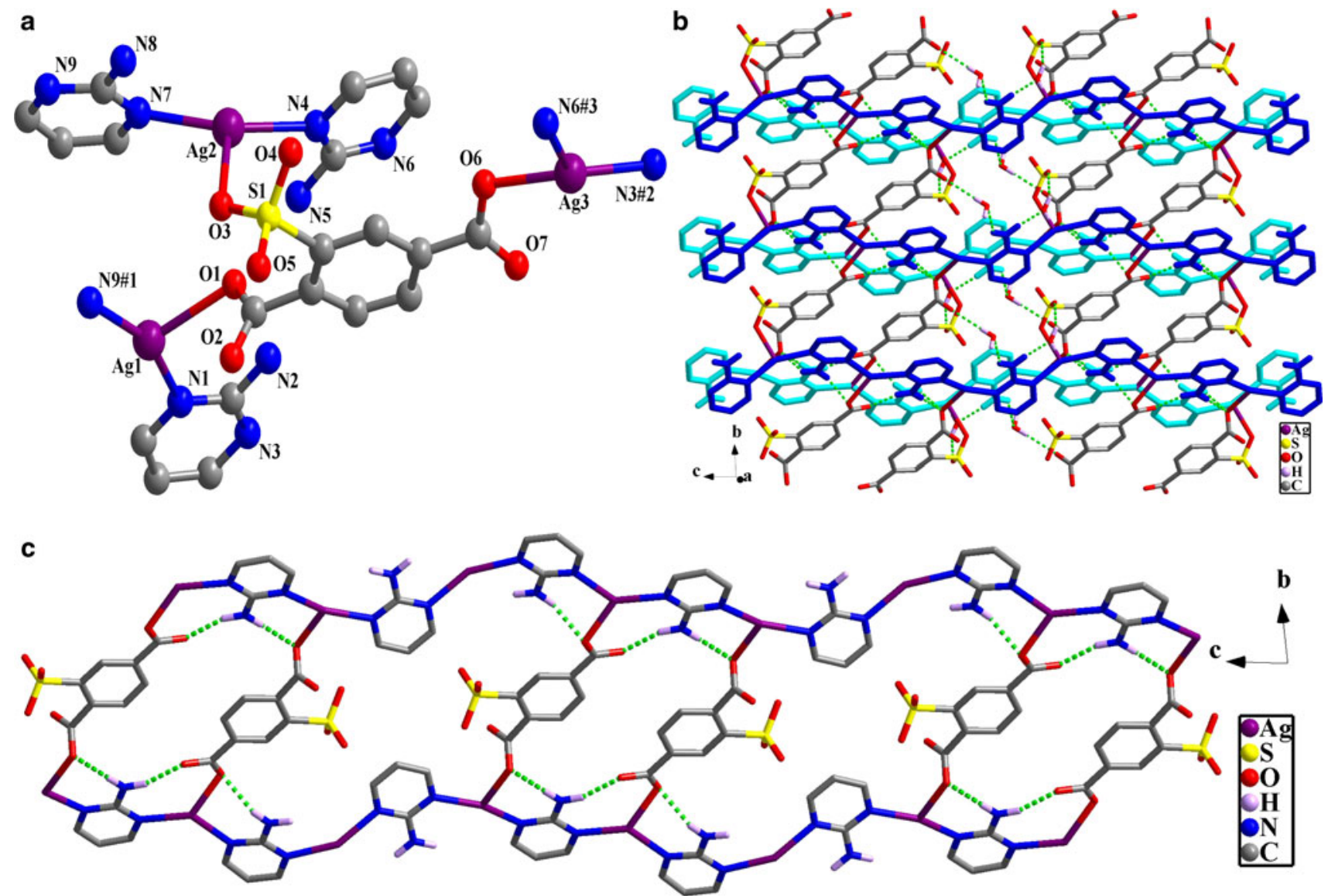

Fig. 1 a Asymmetric unit of $\left\{\left[\mathrm{Ag}_{3}(\mathrm{stp})(\operatorname{apym})_{3}\right] \cdot 2 \mathrm{H}_{2} \mathrm{O}\right\}_{n}$ (1) and coordination environments around the $\mathrm{Ag}(\mathrm{I})$ atoms. Water molecules and corresponding $\mathrm{H}$ atoms are omitted for clarity. $\mathbf{b}$ The 2-D laminar structure in complex 1 based on the $\mathrm{Ag}(\mathrm{I})$ atoms, stp and apym ligands along $a \times b \times c$ plane. $\mathbf{c}$ View of the 1-D double chain in complex 1 along the $a$ axis 
Table 3 Hydrogen bonds for complexes 1 and $2\left(\AA^{\circ}\right.$ and $\left.{ }^{\circ}\right)$

\begin{tabular}{|c|c|c|c|c|}
\hline $\mathrm{D}-\mathrm{H} \cdots \mathrm{A}$ & $\mathrm{d}(\mathrm{D}-\mathrm{H})$ & $\mathrm{d}(\mathrm{H} \cdots \mathrm{A})$ & $<($ DHA $)$ & $\mathrm{d}(\mathrm{D} \cdots \mathrm{A})$ \\
\hline $\multicolumn{5}{|c|}{\left[\mathrm{Ag}_{3}(\mathrm{stp})(\mathrm{apym})_{3}\right] \cdot 2 \mathrm{H}_{2} \mathrm{O}}_{n}(\mathbf{1})$ \\
\hline $\mathrm{N}(8)-\mathrm{H}(8 \mathrm{~B}) \cdots \mathrm{O}(8)$ & 0.90 & 1.96 & 173.0 & $2.852(5)$ \\
\hline $\mathrm{N}(8)-\mathrm{H}(8 \mathrm{~A}) \cdots \mathrm{O}(5) \# 5$ & 0.90 & 2.64 & 132.3 & $3.312(6)$ \\
\hline $\mathrm{N}(8)-\mathrm{H}(8 \mathrm{~A}) \cdots \mathrm{O}(9) \# 6$ & 0.90 & 2.38 & 125.8 & 2.993(7) \\
\hline $\mathrm{N}(5)-\mathrm{H}(5 \mathrm{~B}) \cdots \mathrm{O}(1)$ & 0.90 & 2.16 & 133.6 & $2.853(5)$ \\
\hline $\mathrm{N}(5)-\mathrm{H}(5 \mathrm{~A}) \cdots \mathrm{O}(6) \# 4$ & 0.90 & 2.13 & 148.7 & $2.934(5)$ \\
\hline $\mathrm{N}(2)-\mathrm{H}(2 \mathrm{~B}) \cdots \mathrm{O}(7)$ & 0.90 & 2.03 & 160.1 & $2.890(5)$ \\
\hline $\mathrm{N}(2)-\mathrm{H}(2 \mathrm{~A}) \cdots \mathrm{O}(1)$ & 0.90 & 2.08 & 177.0 & $2.983(5)$ \\
\hline $\mathrm{O}(9)-\mathrm{H}(9 \mathrm{C}) \cdots \mathrm{O}(2) \# 7$ & 0.85 & 2.33 & 159.0 & $3.142(7)$ \\
\hline $\mathrm{O}(8)-\mathrm{H}(8 \mathrm{E}) \cdots \mathrm{O}(4)$ & 0.85 & 2.12 & 132.6 & $2.769(5)$ \\
\hline $\mathrm{O}(8)-\mathrm{H}(8 \mathrm{C}) \cdots \mathrm{O}(2) \# 8$ & 0.85 & 2.02 & 130.0 & $2.651(5)$ \\
\hline \multicolumn{5}{|c|}{$\begin{array}{l}\text { Symmetry codes: \#4 } x, y+1, z ; \# 5-x+2,-y,-z ; \# 6-x+1,-y+1,-z ; \# 7 x-1, y+1, z ; \# 8 x-1, y, z \\
\left\{\left[\mathrm{Ag}_{2}(\mathrm{Hstp})(\text { dapym })_{2}\left(\mathrm{H}_{2} \mathrm{O}\right)\right] \cdot \mathrm{H}_{2} \mathrm{O}\right\}_{n}(\mathbf{2})\end{array}$} \\
\hline $\mathrm{N}(6)-\mathrm{H}(6 \mathrm{~B}) \cdots \mathrm{O}(1)$ & 0.86 & 2.39 & 136.3 & $3.072(4)$ \\
\hline $\mathrm{N}(6)-\mathrm{H}(6 \mathrm{~B}) \cdots \mathrm{O}(3)$ & 0.86 & 2.33 & 138.5 & $3.027(7)$ \\
\hline $\mathrm{N}(6)-\mathrm{H}(6 \mathrm{~B}) \cdots \mathrm{O}\left(3^{\prime}\right)$ & 0.86 & 2.09 & 139.6 & $2.802(7)$ \\
\hline $\mathrm{N}(6)-\mathrm{H}(6 \mathrm{~A}) \cdots \mathrm{O}\left(4^{\prime}\right) \# 2$ & 0.86 & 1.99 & 167.0 & $2.838(7)$ \\
\hline $\mathrm{N}(6)-\mathrm{H}(6 \mathrm{~A}) \cdots \mathrm{O}(4) \# 2$ & 0.86 & 1.91 & 168.7 & $2.757(6)$ \\
\hline $\mathrm{N}(3)-\mathrm{H}(3 \mathrm{~B}) \cdots \mathrm{O}(1)$ & 0.86 & 2.54 & 137.7 & $3.224(4)$ \\
\hline $\mathrm{N}(3)-\mathrm{H}(3 \mathrm{~A}) \cdots \mathrm{O}(8) \# 3$ & 0.86 & 2.07 & 163.0 & $2.905(4)$ \\
\hline $\mathrm{O}(9)-\mathrm{H}(9 \mathrm{C}) \cdots \mathrm{N}(4) \# 4$ & 0.85 & 2.61 & 148.5 & $3.366(5)$ \\
\hline $\mathrm{O}(9)-\mathrm{H}(9 \mathrm{~B}) \cdots \mathrm{O}(3) \# 4$ & 0.85 & 2.18 & 118.5 & $2.696(7)$ \\
\hline $\mathrm{O}(8)-\mathrm{H}(8 \mathrm{C}) \cdots \mathrm{O}(9)$ & 0.85 & 1.98 & 151.4 & $2.761(5)$ \\
\hline $\mathrm{O}(8)-\mathrm{H}(8 \mathrm{~B}) \cdots \mathrm{O}(2)$ & 0.85 & 1.88 & 154.5 & $2.671(4)$ \\
\hline $\mathrm{O}(7)-\mathrm{H}(7) \cdots \mathrm{O}(2) \# 6$ & 0.82 & 2.65 & 128.2 & $3.221(4)$ \\
\hline $\mathrm{O}(7)-\mathrm{H}(7) \cdots \mathrm{O}(1) \# 6$ & 0.82 & 1.76 & 171.7 & $2.577(3)$ \\
\hline
\end{tabular}

Crystal structure of complex 2

The complex 2 crystallizes in the monoclinic $P 2_{1 / \mathrm{c}}$ space group. The asymmetric unit of $\mathbf{2}$ contains two $\mathrm{Ag}(\mathrm{I})$ atoms, one Hstp ligand, two dapym ligands, and one aqua ligand, as well as one lattice water molecule. As illustrated in Fig. 2a, the Ag1 adopts a $T$-shaped geometry completed by one oxygen from the Hstp ligand and two nitrogen atoms from different dapym ligands. The maximum angle around Ag1 is 157.36(9) $\AA$. Atom Ag2 is located in a distorted tetrahedral geometry with one aqua ligand, one oxygen atom from an Hstp ligand, and two nitrogen atoms from two dapym ligands as donors. Each dapym ligand uses the $\mu_{2}-\eta^{1}: \eta^{1}$ bidentate coordination mode to bridge two adjacent $\operatorname{Ag}(\mathrm{I})$ atoms. As a consequence, the $\operatorname{Ag}(\mathrm{I})$ atoms are extended by the dapym ligand spacers to afford a 1-D chain almost along the [001] direction (Fig. 2c), within which the distance between successive $\operatorname{Ag}(\mathrm{I})$ atoms is 6.142(9) $\AA$. The Hstp ligand acts as a linker to equip a 2-D layer (Fig. 2b) by connecting two neighboring parallel coordination chains through $\mathrm{Ag}-\mathrm{O}$ coordination, as well as intermolecular hydrogen bond interactions with the coordinated carboxylate and sulfo group oxygen atoms of Hstp ligands, plus further H-bonding involving both coordinated and guest water, as depicted in Table 3.

\section{Thermogravimetric and photoluminescence analyses}

Thermogravimetric (TG) analysis was performed under an $\mathrm{N}_{2}$ atmosphere on crystalline samples of complexes $\mathbf{1}$ and $\mathbf{2}$ (Fig. 3a). The TG curve of $\mathbf{1}$ shows the first weight loss of $4.12 \%$ in the temperature range $40-80{ }^{\circ} \mathrm{C}$, associated with the exclusion of two lattice water molecules (calcd $4.85 \%$ ); then, from 200 to $700{ }^{\circ} \mathrm{C}$, the stp and apym ligands are released in a featureless process, to give a residue of $\mathrm{Ag}_{2} \mathrm{SO}_{4}$. Complex 2 starts to lose one lattice water molecule in the temperature range $40-80{ }^{\circ} \mathrm{C}$ (obsd $1.74 \%$; calcd $2.02 \%$ ), and then, the curve shows further decomposition in the temperature range $200-250{ }^{\circ} \mathrm{C}$ with a 

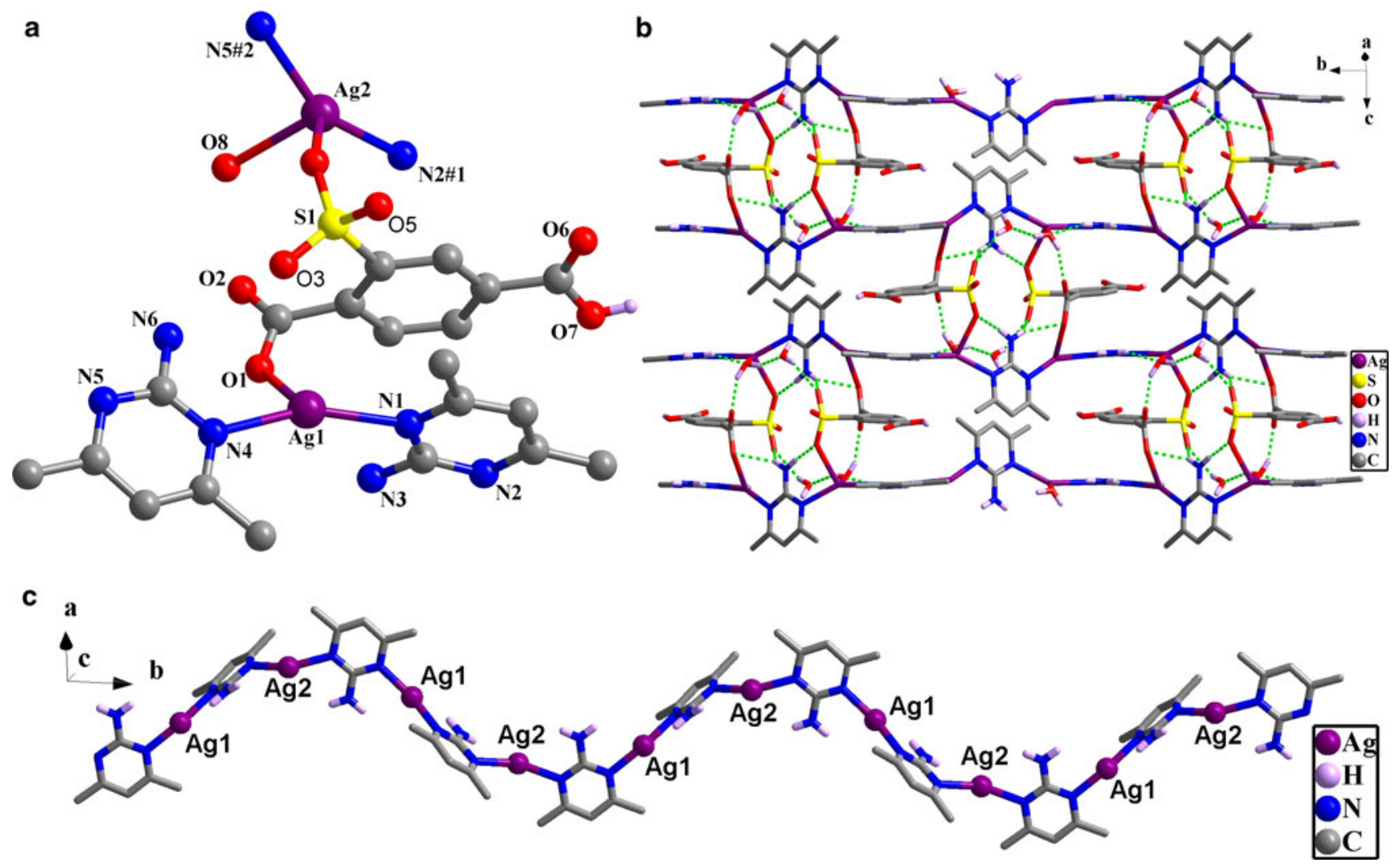

Fig. 2 a Asymmetric unit of $\left\{\left[\mathrm{Ag}_{2}(\mathrm{Hstp})(\text { dapym })_{2}\left(\mathrm{H}_{2} \mathrm{O}\right)\right] \cdot \mathrm{H}_{2} \mathrm{O}\right\}_{n}(\mathbf{2})$ and coordination environments around the $\operatorname{Ag}(\mathrm{I})$ atoms. Water molecules and corresponding $\mathrm{H}$ atoms are omitted for clarity. b 2-D layer structure in complex 2 consisting of hydrogen bonds. c 1-D metal-organic polymer based on the $\mathrm{Ag}(\mathrm{I})$ atoms and dapym ligands
Fig. 3 a TGA curves for complexes $\mathbf{1}$ and $\mathbf{2}$. b The solidstate emission photoluminescent spectra of $\mathbf{1}\left(\lambda_{\mathrm{ex}}=390 \mathrm{~nm}\right), \mathbf{2}$ $\left(\lambda_{\mathrm{ex}}=290 \mathrm{~nm}\right)$ and free $\mathrm{H}_{3} \mathrm{stp}$ $\left(\lambda_{\mathrm{ex}}=321 \mathrm{~nm}\right)$ at room temperature

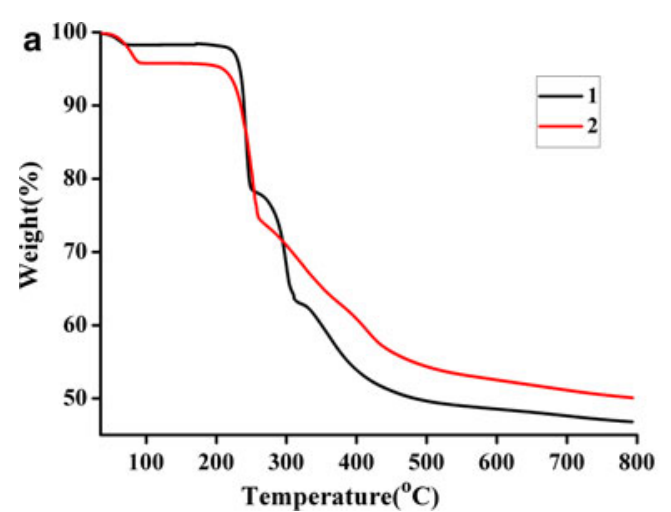

$20.00 \%$ weight change, corresponding to loss of the dapym ligand (calcd $20.08 \%$ ). The third weight loss of $13.72 \%$ (calcd $12.72 \%$ ) corresponds to the loss of the Hstp ligands and one aqua ligand without a clear inflection.

The luminescence properties of both complexes and free $\mathrm{H}_{3}$ stp were studied in the solid state. As shown in Fig. 3b, very similar emission bands were observed for the two complexes, while emission of the free $\mathrm{H}_{3}$ stp ligand with $\lambda_{\mathrm{em}}=437 \mathrm{~nm}\left(\lambda_{\mathrm{ex}}=321 \mathrm{~nm}\right)$ was observed, which is probably attributable to $\pi^{*} \rightarrow n$ or $\pi^{*} \rightarrow \pi$ transitions. Compared to the spectrum of the free ligand, the emission band of complex $\mathbf{1}$ is red-shifted by $15 \mathrm{~nm}$. The shift can be attributed to ligand to metal charge transfer (LMCT), involving the filled $\mathrm{p}$ orbitals of coordinated $\mathrm{N}$ atoms and the vacant $5 \mathrm{~s}$ orbitalof $\mathrm{Ag}(\mathrm{I})$, mixed with metal-centered (d-s/d-p) transitions [30-32]. In contrast to complex $\mathbf{1}$, the emission band of 2 is blue-shifted by more than $65 \mathrm{~nm}$, which could be assigned to $\pi^{*} \rightarrow \pi$ electronic transitions of the ligand. The blue shift of the emission compared with that of the free ligand may be attributed to coordination of the ligand to $\operatorname{Ag}(\mathrm{I})$, enhancing its conformational rigidity and decreasing the non-radiative energy loss [12]. 
Generally speaking, $\operatorname{Ag}(\mathrm{I})$ complexes emit weak photoluminescence at low temperature, owing to the intense spinorbital coupling of $\operatorname{Ag}(\mathrm{I})[12,33,34]$. Consequently, complexes $\mathbf{1}$ and $\mathbf{2}$ are unusual examples of room temperature luminescent Ag-containing polymers.

\section{Conclusions}

From the reactions of $\mathrm{AgNO}_{3}, 2$-sulfoisophthalic acid, and $\mathrm{N}$-donor ligands, we synthesized and structurally characterized two $\operatorname{Ag}(\mathrm{I})$ coordination complexes, in which the auxiliary ligands are different. This investigation may supply some new information for the design and crystal engineering of such crystalline materials. In addition, these complexes display modest thermal stability and solid-state fluorescent emission. Further studies in this respect are under way in our laboratory.

\section{Supplementary material}

CCDC 912814, 912815 contain the supplementary crystallographic data for complexes $\mathbf{1}$ and $\mathbf{2}$. These data can be obtained free of charge from The Cambridge Crystallographic Data Centre via http://www.ccdc.cam.ac.uk/deposit or from the Cambridge Crystallographic Data Centre, 12 Union Road, Cambridge CB2 1EZ, UK [Telephone: +4401223-762910; Fax:+44-01223-336033; E-mail: deposit@ ccdc.cam.ac.uk].

Acknowledgments We gratefully acknowledge financial support of this work by the Nation Natural Science Foundation of China (Grant Nos. 21271143 and 21171133), the Opening Foundation of Zhejiang Provincial Top Key Discipline (No. 100061200132).

Open Access This article is distributed under the terms of the Creative Commons Attribution License which permits any use, distribution, and reproduction in any medium, provided the original author(s) and the source are credited.

\section{References}

1. Zhang M-D, Di C-M, Qin L, Yao X-Q, Li Y-Z, Guo Z-J, Zheng H-G (2012) Cryst Growth Des 12:3957-3963

2. Li B, Zhang S-Q, Ji C, Hou H-W, Mak TC (2012) Cryst Growth Des 12:1443-1451

3. Cheng L, Zhang L-M, Cao Q-G, Gou S-H, Zhang X-Y, Fang L (2012) Cryst Eng Commun 14:7502-7510
4. Wu C-J, Lin C-Y, Cheng P-C, Yeh CW, Chen J-D, Wang J-C (2011) Polyhedron 30:226-2267

5. Zhang Q-L, Zhu BX, Zhang Y-Q, Tao Z, Clegg JK, Lindoy LF, Wei G (2011) Cryst Growth Des 11:5688-5695

6. Sun S, Ren Z-G, Yang J-H, He R-T, Wang F, Wu X-Y, Li H-X, Lang J-P (2012) Dalton Trans 41:8447-8454

7. Henkelis JJ, Barnett SA, Harding LP, Hardie MJ (2012) Inorg Chem 51:10657-10674

8. Li D-H, Shen J-S, Chen N, Ruan Y-B, Jiang Y-B (2011) Chem Commun 47:5900-5902

9. Yao X-Q, Li C-J (2005) J Org Chem 70:5752-5755

10. Caballero A, Maclaren JK, Diéguez AR, Vidal I, Dobado JA, Salas JM, Janiak C (2011) Dalton Trans 40:11845-11855

11. Zhang P-P, Peng J, Pang H-J, Sha J-Q, Zhu M, Wang D-D, Liu M-G, Su Z-M (2011) Cryst Growth Des 11:2736-2742

12. Wang C-C, Li H-Y, Guo G-L, Wang P (2013) Transition Met Chem 38:275-282

13. Attenberger B, Welsch S, Zabel M, Peresypkina E, Scheer M (2011) Angew Chem Int Ed 50:1-5

14. Hao H-J, Sun D, Li Y-H, Liu F-J, Huang R-B, Zheng L-S (2011) Cryst Growth Des 11:3564-3578

15. Chen J, Hou L, Zhang Y-N, Cui L, Shi Q-Z, Wang Y-Y (2012) Inorg Chem Commun 24:73-76

16. Li C-P, Chen J, Yu Q, Du M (2010) Cryst Growth Des 10:1623-1632

17. Ren Y-X, Xiao S-S, Zheng X-J, Li L-C, Jina L-P (2012) Dalton Trans 41:2639-2647

18. Xiao S-S, Zheng X-J, Yan S-H, Deng X-B, Jin L-P (2010) Cryst Eng Commun 12:3145-3151

19. Horike S, Matsuda R, Tanaka D, Matsubara S, Mizuno M, Endo K, Kitagawa S (2006) Angew Chem Int Ed 45:7226-7230

20. Liu Q-Y, Xu L (2006) Eur J Inorg Chem 26:1620-1628

21. Horike S, Matsuda R, Tanaka D, Mizuno M, Endo K, Kitagawa S (2006) J Am Chem Soc 128:4222-4223

22. Zheng X-F, Zhu L-G (2011) Inorg Chim Acta 365:419-429

23. Gandolfo CM, LaDuca RL (2011) Cryst Growth Des 11:1328-1337

24. Liu Z-S, Yang E, Kang Y, Zhang J (2011) Inorg Chem Commun 14:355-357

25. Li C-P, Yu Q, Chen J, Du M (2010) Cryst Growth Des 10:2650-2660

26. Sun D, Wang D-F, Han X-G, Huang R-B, Zheng L-S (2011) Chem Commun 47:746-748

27. Chainok K, Neville SM, Gee WJ, Murray KS, Batten SR (2012) Cryst Eng Commun 14:3717-3726

28. Yang M-X, Chen L-J, Lin S, Chen X-H, Huang H (2011) Dalton Trans 40:1866-1872

29. Wang J, Cai J-M, Wang A-Y, Huang B-F, Xiao H-P, Li X-H, Morsali A (2013) Inorg Chim Acta 394:466-471

30. Sun D, Zhang N, Xu Q-J, Huang R-B, Zheng L-S (2010) J Mol Struct 975:17-22

31. Liu C-S, Chang Z, Wang J-J, Yan L-F, Bu X-H, Batten SR (2008) Inorg Chem Commun 11:889-892

32. Sun D, Wang D-F, Zhang N, Liu F-J, Hao H-J, Huang R-B, Zheng L-S (2011) Dalton Trans 40:5677-5679

33. Genuis ED, Kelly JA, Patel M, McDonald R, Ferguson MJ, Strom GG (2008) Inorg Chem 47:6184-6190

34. Li B, Zang S-Q, Ji C, Liang R, Hou H-W, Wua YJ, Mak TC (2011) Dalton Trans 40:10071-10081 